\title{
Disparities in receipt of recommended care among younger versus older medicare beneficiaries: a cohort study
}

\author{
Ling $\mathrm{Na}^{1}$, Joel E. Streim², Liliana E. Pezzin ${ }^{3,4}$, Jibby E. Kurichi ${ }^{1}$, Dawei Xie ${ }^{1}$, Hillary R. Bogner ${ }^{1}$, Pui L. Kwong ${ }^{1}$,
} Steven M. Asch ${ }^{5}$ and Sean Hennessy ${ }^{1,6^{*}}$

\begin{abstract}
Background: Although health disparities have been documented between Medicare beneficiaries based on age ( $<65$ years vs. older age groups), underuse of recommended medical care in younger beneficiaries has not been thoroughly investigated. In this study, we aim to identify and characterize vulnerabilities of the younger Medicare age group (aged $<65$ years) in relation to older age groups (aged 65-74 years and $\geq 75$ years) and to explore age group as a determinant of use of recommended care among Medicare beneficiaries.

Methods: We conducted a cohort study of community-dwelling Medicare beneficiaries who participated in the Medicare Current Beneficiary Survey between 2001 and 2008 ( $N=30,117)$. Age group characteristics were compared using cross-sectional data at baseline. During follow-up, we assessed the association between age and receipt of recommended care on 38 recommended care indicators, adjusting for sociodemographic and clinical characteristics. Follow-up periods differed by component indicator.

Results: At baseline, a higher proportion of younger beneficiaries experienced social disadvantage, disability and certain morbidities than older age groups. During follow-up, younger beneficiaries were significantly less likely to receive overall recommended care compared to those 65-74 years of age (adjusted odds ratio and 95\% confidence interval: 0.75, 0.70-0.80). In addition, male gender, non-Hispanic black race, less than high school education, living alone, with children or with others, psychiatric disorders and higher activity limitation stages were all associated with underuse of recommended care.
\end{abstract}

Conclusions: Younger Medicare beneficiary status appears to be an independent risk factor for underuse of appropriate care. Support to ameliorate disparities in different social and health aspects may be warranted.

Keywords: Medicare, Younger beneficiaries, Health disparity, Recommended care, Quality of care

\section{Background}

The Healthy People 2020 initiative seeks to eliminate health disparities and improve the health of all groups in the US [1]. A distinct group that suffers multiple health disparities, yet has not been investigated thoroughly, is Medicare beneficiaries under 65 years of age. Younger Medicare beneficiaries face major social disadvantages and a disproportionately high burden of disabilities and

\footnotetext{
* Correspondence: hennessy@upenn.edu

${ }^{1}$ Center for Clinical Epidemiology and Biostatistics, Perelman School of

Medicine, University of Pennsylvania, Philadelphia, PA, USA

${ }^{6}$ Center for Pharmacoepidemiology Research and Training, University of

Pennsylvania, Philadelphia, PA, USA

Full list of author information is available at the end of the article
}

medical morbidities. Unlike those who are eligible for Medicare solely due to being 65 years of age and older, younger enrollees must have received Social Security disability benefits for 24 months or have either amyotrophic lateral sclerosis or end-stage renal disease [2]. Younger Medicare beneficiaries are more likely to be male, non-white, economically and educationally disadvantaged, to be in fair or poor health, and to have a higher prevalence of disabilities and mental health disorders [3-6]. In 2012, younger beneficiaries constituted $17 \%$ of the 50.8 million Medicare enrollees, but triggered $20 \%$ of total Medicare expenditures [7]. Despite these higher expenditures, they underutilized preventive health 
services including influenza vaccine, eye and dental exams, mammograms, and prostate exams [4].

Braveman's health disparity framework lays the ground for our analysis of younger Medicare beneficiaries [8]. A health disparity is a population-specific, potentially avoidable difference in health or important influences on health that is systematically associated with socially disadvantaged groups [8], such as the impoverished, racial minorities and individuals with disabilities. An important way to eliminate health disparities is through equitable health care, defined as equally accessible care to all users, and greater provision of care to users who demonstrate greater need [8-10]. In Braveman's framework, a health disparity should be assessed by comparing groups in a social hierarchy in relation to each other [11], because such comparisons help policy makers identify vulnerable social groups, target interventions and reallocate resources to achieve greater health equity. Factors associated with health disparities include minority race $[12,13]$, lower income and less education [14], and disability [15-17]. Often these vulnerabilities, as well as rural location and reduced physician supply, are also associated with poor quality of care [18-25]. Although it is expected that younger beneficiary status is associated with health disparity due to Medicare enrollment criteria, younger beneficiaries demonstrated largely unmet health care needs.

However, younger beneficiaries are often excluded from studies of Medicare beneficiaries. The few pioneering studies comparing younger versus older beneficiaries highlighted the importance of the topic, although they tend to have several limitations [4-6]: self-reported health service utilization is subject to recall bias; types of services are often limited to preventive care; and crude associations without risk adjustment are not particularly useful for policy planning. To better capture underuse of care in the younger population, we employed claims data, a variety of indicators and risk-adjusted models. Furthermore, three main characteristics of younger beneficiaries (greater comorbidity, disability and socioeconomic disadvantages) do not always affect quality of care in the same direction. Multimorbid patients tend to get higher quality of care [26], disability has mixed quality [24]; minority race and lower income, while also having mixed quality, tend to predict worse care [21, 27]. Comparing younger with older Medicare beneficiaries can shed light on the direction and magnitude of these relationships, and their synergies and dys-synergies as they co-occur in younger beneficiary population. The comparison is important as a policy evaluation issue: is the Medicare program failing its younger beneficiaries?

We sought to identify predictors of underuse of recommended care by applying Asch's underuse indicator system to recent Medicare claims of health service utilization [21]. Asch's underuse indicator system is a clinically valid, comprehensive and claim-based measurement tool, which examines highly prevalent conditions and preventive care. These indicators have been validated on both inpatient, outpatient and physician service claims data for Medicare beneficiaries 65 years of age and older [21, 24], but not younger beneficiaries. Therefore, we aimed to characterize vulnerabilities of the younger Medicare age group and then explore age group as a determinant of use of recommended care among Medicare enrollees. We assess the extent to which the earlier findings of disparities in sociodemographic and health characteristics hold in younger beneficiaries in our data. We further test our hypothesis that compared to older beneficiaries, younger beneficiaries are less likely to receive recommended care after accounting for sociodemographic characteristics, degree of comorbidity and activity limitation.

\section{Methods \\ Study sample}

We analyzed data from a nationally representative sample of the Medicare population, the Medicare Current Beneficiary Survey (MCBS) $[28,29]$. The MCBS is a longitudinal panel survey that contains individual-level information of sociodemographics, health care encounters and health and physical functioning. Survey participants are typically interviewed three times per year for 4 years with health and functioning assessed in the fall of each year. The sample is replenished annually with newly enrolled beneficiaries replacing those who died or exited the survey. Survey data are linked to Medicare claims data that are available for 3 years after the initial survey. The MCBS uses multistage sampling design, with weights, strata and cluster information available. MCBS oversamples beneficiaries aged 85 years and older and those aged 65 years and younger. One study reported that the initial response rate of MCBS was $82.6 \%$, similar to other national surveys [29]. The response rates were $82-83 \%$ across different age categories. The magnitude of potential bias due to non-response was reduced by non-response adjustment provided in the survey [29]. Our study included community-dwelling Medicare beneficiaries who enrolled in the MCBS between 2001 and 2008 . The entry panels of 2001-2007 were followed for 3 years, and panel 2008 was followed for 2 years because claims data beyond 2010 were not available.

The study was approved by the University of Pennsylvania Institutional Review Board.

\section{Receipt of recommended care}

To assess receipt of recommended care, we adapted the indicator system measuring underuse of necessary care 
that was developed by Asch and colleagues [21] and later modified by Chan [24]. The original indicators span several domains of care: initial evaluation, diagnostic tests, therapeutic interventions, hospitalization follow-up, monitoring of routine care and avoidable outcomes. The indicator system was tested and validated on 1992-1993 Medicare claims and was applied to 1994-1996 claims data [21]. After excluding six avoidable outcome indicators (because we wished to focus on process measures) and three indicators with inadequate sample size, we adapted 38 indicators or process measures, of recommended care to our study. Three of these 38 indicators measured receipt of preventive care: a physician annual visit, a biennial visual impairment assessment, and a biennial mammography for women aged between 45 and 75 years. The remaining 35 indicators examined care for acute and chronic conditions, including acute myocardial infarction, anemia, angina, breast cancer, cerebrovascular accident (CVA), transient ischemic attack (TIA), cholelithiasis, chronic obstructive pulmonary disease (COPD), congestive heart failure (CHF), depression, diabetes, gastrointestinal bleeding and hypertension.

Each indicator specified which beneficiaries were eligible (i.e., had an opportunity) for its assessment, the care that should be received, and a recommended time interval. Receipt of recommended care was coded as present if claims data indicated delivery of care within the recommended time frame, and absent otherwise. Receipt of care was assessed at the opportunity level; thus a beneficiary might have multiple opportunities for recommended care. Opportunities were not eligible for indicator assessment if they had incomplete follow-up time due to death or loss to follow-up, disenrollment in Part A and/or part B, or enrollment in a managed care program during the assessment period. For indicators with short assessment periods (2-4 weeks), subjects were excluded if there was a hospitalization or ER visit during the follow-up period.

\section{Age groups}

Our main interest was Medicare beneficiaries younger than age 65 . Recognizing the potential heterogeneity of older beneficiaries in their health status and health care quality [5], we classified them as younger old (65-74 years) and older old (75 years and older).

\section{Sociodemographic and clinical characteristics}

Sociodemographics and clinical characteristics were assessed based on self- or proxy-report in the surveys. Sociodemographics included sex, race (non-Hispanic white, non-Hispanic black, Hispanic or other), education (less than high school education or high school diploma and above), dual enrollment in Medicare and Medicaid, living arrangement (alone, with spouse, with children, with others or in a retirement community), and residential location (metropolitan or non-metropolitan area). Health and clinical characteristics were self-reported and included number of comorbidities (hypertension, myocardial infarction, angina/chronic heart disease, other heart disease, stroke, diabetes mellitus, Parkinson's disease, emphysema/asthma/chronic obstructive pulmonary disease, rheumatoid arthritis, non-rheumatoid arthritis, osteoporosis/soft bones and cancers other than skin), presence of a developmental, psychiatric or cognitive disorder (mental retardation, Alzheimer's/dementia or mental/psychiatric disorders), vision impairment, and hearing impairment. In addition, we included an indicator of proxy versus self-response to the survey. We chose not to use specific conditions or comorbidity indices based on claims ICD-9 codes because the assessment periods of these indices partially overlap with indicatorlevel follow-up periods, instead of preceding follow-up periods.

\section{Activity limitation stages}

Activity limitation stages based on the International Classification of Functioning Disability and Health (ICF) [30] in separate activity of daily living (ADL) and instrumental activity of daily living (IADL) domains were derived from survey data for each respondent. ADL stages include the self-care functions of eating, toileting, dressing, bathing or showering, getting in/out of bed or chairs and walking. IADL stages incorporate the domestic life functions of telephoning, managing money, preparing meals, doing light housework, shopping for personal items and doing heavy housework. Five ADL stages $(0-I V)$ and five IADL stages (0-IV) present a combination of severity and types of disability (Appendix). Stage III was designed as a non-fitting stage to characterize unusual limitation patterns. Methods for ascertaining stage are documented elsewhere [31,32].

\section{Statistical analysis}

Chi-square tests were used to assess differences in baseline characteristics among the three age groups. Pairwise chi-square tests were applied to statistically significant between-group differences, with the younger and older old compared to the younger old. Receipt of recommended care was expressed as a percent by dividing the number of instances of recommended care received by the number of opportunities. We calculated the weighted percent of receipt of overall (collapsed across the 38 indicators) and indicator-specific recommended care for all age groups combined and for each age group separately. The association between age group and receipt of overall 
recommended care was assessed first in an unadjusted logistic regression model, and subsequently in multivariable logistic regression. Separate adjusted models were fit for ADL and IADL stages because collinearity precludes including both domains in a single model. Age group and covariates including sex, race and education were assessed at baseline, and other covariates that may vary over time were assessed in the survey cycle immediately preceding indicator the follow-up date. The model applied survey sampling weights and accounted for the complex sampling design and non-independence of multiple eligible indicators for the same individual. Analyses were conducted using SAS 9.4 (SAS Institute, Cary, NC).

\section{Results}

\section{Sample characteristics}

The distribution of the baseline sample $(N=30,117)$ by age group was $16 \%$ were younger than age 65 years, $48 \%$ aged $65-74$ years, and $36 \%$ aged 75 years and older. Table 1 lists baseline characteristics by age group. The most striking sociodemographic differences among the age groups were in race/ethnicity, living arrangement and dual enrollment. Compared to the older groups, younger beneficiaries were more likely to be nonHispanic black (19\% vs. $9 \%$ and $7 \%$ ) and Hispanic (11\% vs. $8 \%$ and $6 \%)$, to live with others ( $24 \%$ vs. $5 \%$ and $4 \%)$, and to be dually-enrolled in Medicaid ( $44 \%$ vs. $11 \%$ and $12 \%)$.

Younger beneficiaries carried a disproportionate burden of developmental, cognitive and psychiatric disorders (39\% vs. $7 \%$ and $8 \%$ ). They were significantly less likely to be functionally independent in ADLs (stage 0) compared to the other two older age groups (45\% vs. $80 \%$ and 64\%). Differences in IADL stages were even more striking: only $24 \%$ of younger beneficiaries were IADL independent (stage 0) compared to $74 \%$ of the younger old and $56 \%$ of the older old. They relied more heavily on proxy responses to survey questions and were more likely to be visually impaired.

\section{Receipt of recommended care by age group across all indicators}

In total 20,449 unique beneficiaries were eligible for at least one opportunity for recommended care, including 3756 younger, 7180 younger old and 9513 older old beneficiaries. These beneficiaries triggered 89,076 opportunities for care, with 14,015 for younger beneficiaries, 32,372 opportunities for the younger old, and 42,689 for the older old. As shown in Table 2, eligible younger beneficiaries received recommended care in $64 \%$ of the opportunities, in contrast to $73 \%$ for the younger old and $75 \%$ for the older old.
Receipt of recommended care by age group by indicator Table 3 presents the weighted percent of receiving recommended care by age group for each indicator. The Centers for Medicare and Medicaid Services (CMS) prohibits publishing cell size below 11, yielding 30 eligible indicators for comparison, 14 of which had a statistically significant difference $(p<.05)$ in receipt of recommended care by age group, shown in Fig. 1 . Among these 14 indicators, pair-wise chi-square tests showed younger beneficiaries underused care on 10 indicators when compared to the younger old, and the older old group underutilized care on 5 indicators. Younger beneficiaries outperformed younger old for 1 indicator, while the older old did so for 4 indicators. Notably, younger beneficiaries were less likely than the younger old to have a follow-up visit within 4 weeks following hospital discharge for CVA, TIA and gastrointestinal (GI) bleed, to obtain a hematocrit within 4 weeks following an initial diagnosis of GI bleed, to receive routine care for diabetes (a glycosylated hemoglobin every 6 months, an annual eye exam and a doctor visit every 6 months), and preventive care in general (an annual physician visit, a biennial mammogram and a biennial assessment of visual impairment).

Compared to the younger old, the older old beneficiaries were less likely to receive follow-up care for CHF, TIA and CVA after hospital discharge. However, the older old were more likely to attend an annual doctor visit, to have a biennial eye exam, and to receive eye exam for diabetes.

\section{Factors associated with receipt of recommended care}

Table 4 displays the association between age group and receipt of recommended care in a bivariate logistic regression model and multivariable logistic regression models that included ADL and IADL stages separately. In the unadjusted model, the odds of receiving overall recommended care was $34 \%$ lower among younger beneficiaries, but $11 \%$ higher among older old beneficiaries, each compared to the younger old.

Model estimates for separate stage systems were similar (Table 4), after excluding less than $2 \%$ of missing cases. In the multivariable model adjusted for ADL stages, the association (OR) between younger age and receipt of recommended care was attenuated to 0.75. Male gender, black race, less than high school education, living alone, with children or with others (each compared to living with spouse), proxy response and having developmental, cognitive or psychiatric disorders were all independently associated with underuse of recommended care. Living in a metropolitan area and a greater number of comorbidities were associated with appropriate care. Both ADL and IADL stages showed ordered associations with receipt of recommended care. Compared to no ADL limitations (stage 0 ), the likelihood of receiving recommended care declined with higher ADL stages, with ORs (95\% CIs) 
Table 1 Sociodemographic, functional and clinical characteristics of medicare beneficiaries (2001-2008) by age group

\begin{tabular}{|c|c|c|c|c|c|}
\hline Variable & $\begin{array}{l}\text { Total } \\
N=30,117\end{array}$ & $\begin{array}{l}\text { Age }<65 \\
\text { N (column weighted \%) } \\
5201(16.3)\end{array}$ & $\begin{array}{l}\text { Age 65-74 } \\
\text { N (column weighted \%) } \\
11,289(47.5)\end{array}$ & $\begin{array}{l}\text { Age } \geq 75 \\
\mathrm{~N}(\text { column weighted \%) } \\
13,627(36.2)\end{array}$ & $p$-value \\
\hline \multicolumn{5}{|l|}{ Gender } & $<.0001$ \\
\hline Male & $13,649(45.2)$ & $2853(52.6)$ & $5360(46.3)$ & $5436(40.3)$ & \\
\hline Female & $16,468(54.8)$ & $2348(47.4)$ & $5929(53.7)$ & $8191(59.7)$ & \\
\hline \multicolumn{5}{|l|}{ Race/Ethnicity } & $<.0001$ \\
\hline Non-Hispanic White & 23,893 (79.2) & $3459(67.3)$ & 9017 (79.9) & $11,417(83.7)$ & \\
\hline Non-Hispanic Black & $2966(9.7)$ & 1007 (18.6) & $1007(8.7)$ & $952(7.0)$ & \\
\hline Hispanic & $2372(7.9)$ & $580(11.2)$ & $913(8.0)$ & $879(6.3)$ & \\
\hline Other & $886(3.2)$ & $155(2.9)$ & $352(3.4)$ & $379(2.9)$ & \\
\hline \multicolumn{5}{|l|}{ Living arrangement } & $<.0001$ \\
\hline Retirement community & 1905 (5.6) & $101(2.2)$ & $430(3.6)$ & $1374(9.7)$ & \\
\hline With spouse & $14,124(51.2)$ & 1649 (39.1) & 7004 (62.6) & $5471(41.6)$ & \\
\hline With children & $3158(9.5)$ & $658(11.4)$ & $802(7.0)$ & $1698(12.1)$ & \\
\hline With others & $2762(7.8)$ & $1597(23.6)$ & $589(5.2)$ & $576(4.2)$ & \\
\hline Alone & $8168(25.9)$ & $1196(23.8)$ & 2464 (21.6) & $4508(32.5)$ & \\
\hline \multicolumn{5}{|c|}{ Dual enrollment in Medicare and Medicaid } & $<.0001$ \\
\hline No & $24,292(83.5)$ & $2409(56.4)$ & $9984(89.4)$ & $11,899(87.8)$ & \\
\hline Yes & $5825(16.5)$ & $2792(43.6)$ & 1305 (10.6) & $1728(12.2)$ & \\
\hline \multicolumn{5}{|l|}{ Education } & $<.0001$ \\
\hline High school diploma or above & $21,252(72.8)$ & $3527(69.1)$ & $8543(77.4)$ & $9182(68.5)$ & \\
\hline No high school diploma & $8865(27.2)$ & $1674(30.9)$ & $2746(22.6)$ & $4445(31.5)$ & \\
\hline \multicolumn{5}{|l|}{ Living in metropolitan area } & $<.0001$ \\
\hline No & $7942(25.0)$ & $1598(29.0)$ & $3092(25.1)$ & $3252(23.1)$ & \\
\hline Yes & $22,175(75.0)$ & $3603(71.0)$ & $8197(74.9)$ & $10,375(76.9)$ & \\
\hline \multicolumn{5}{|l|}{ Proxy report } & $<.0001$ \\
\hline No & $27,492(92.8)$ & $4277(87.2)$ & $10,757(95.4)$ & $12,458(91.9)$ & \\
\hline Yes & $2625(7.2)$ & $924(12.8)$ & $532(4.6)$ & $1169(8.1)$ & \\
\hline \multicolumn{5}{|l|}{ Vision impairment } & $<.0001$ \\
\hline No & $27,674(92.7)$ & $4621(87.9)$ & $10,752(95.8)$ & $12,301(90.8)$ & \\
\hline Yes & $2443(7.3)$ & $580(12.1)$ & $537(4.2)$ & $1326(9.2)$ & \\
\hline \multicolumn{5}{|l|}{ Hearing impairment } & $<.0001$ \\
\hline No & $27,934(93.5)$ & 4890 (93.8) & $10,745(95.5)$ & $12,299(90.8)$ & \\
\hline Yes & $2183(6.5)$ & $311(6.2)$ & $544(4.5)$ & $1328(9.2)$ & \\
\hline \multicolumn{5}{|c|}{ Cognitive, developmental and psychiatric disorders ${ }^{\mathrm{a}}$} & $<.0001$ \\
\hline No & $25,662(87.3)$ & $2766(60.9)$ & $10,442(93.0)$ & $12,454(91.8)$ & \\
\hline Yes & $4455(12.7)$ & 2435 (39.1) & $847(7.0)$ & $1173(8.2)$ & \\
\hline Average number of comorbidities ${ }^{b}$ & $2.2 \pm 0$ & $2.3 \pm 0$ & $2.1 \pm 0$ & $2.4 \pm 0$ & $<.0001$ \\
\hline \multicolumn{5}{|l|}{ Activity of Daily Living (ADL) Stages } & $<.0001$ \\
\hline 0 & $19,874(68.3)$ & 2599 (45.4) & 8846 (79.9) & $8429(63.5)$ & \\
\hline 1 & $5181(16.5)$ & $1156(25.2)$ & $1398(11.8)$ & $2627(18.9)$ & \\
\hline$\|$ & $2622(7.9)$ & $656(13.7)$ & $568(4.5)$ & $1398(9.6)$ & \\
\hline III & $2047(6.2)$ & $656(13.5)$ & 417 (3.3) & $974(6.7)$ & \\
\hline IV & $393(1.1)$ & $134(2.3)$ & $60(0.5)$ & 199 (1.3) & \\
\hline
\end{tabular}


Table 1 Sociodemographic, functional and clinical characteristics of medicare beneficiaries (2001-2008) by age group (Continued)

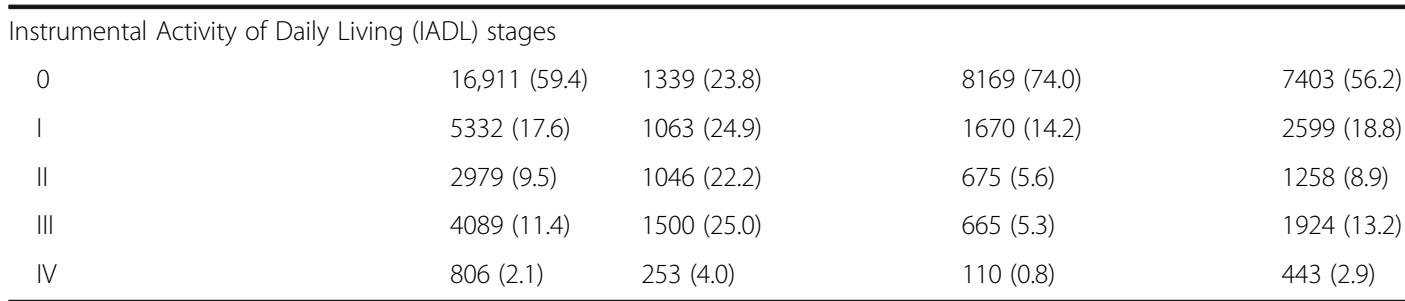

${ }^{a}$ Cognitive, developmental, and psychiatric disorders include: mental retardation, Alzheimer's/dementia and mental/psychiatric disorder

${ }^{b}$ Number of comorbidities including: hypertension, myocardial infarction, angina/chronic heart disease, other heart disease, stroke, diabetes mellitus, Parkinson's disease, emphysema/asthma/chronic obstructive pulmonary disease, rheumatoid arthritis, non-rheumatoid arthritis, osteoporosis/soft bones and other (non-skin) cancer

across stages I-IV at $0.92(0.88-0.97), 0.87(0.81-0.93)$, $0.80(0.74-0.87)$ and $0.64(0.54-0.76)$, respectively. A similar pattern held for IADL stages.

\section{Discussion}

Research on the appropriate use of health services by younger Medicare beneficiaries remains quite limited [3]. In this nationally representative study of community dwelling Medicare beneficiaries, we found that those younger than 65 compared to those 65-74 years of age had a higher proportion of characteristics conventionally associated with social disadvantage. Such characteristics include being non-Hispanic Black, living with disabilities, lower educational achievement and nonmetropolitan residency. Even after adjusting for these factors and further adjusting for dual enrollment in Medicare and Medicaid, cognitive, developmental or psychiatric disorders and vision impairment, we found substantially reduced use of recommended care by younger Medicare beneficiaries. In contrast, the older old group was slightly more likely than the younger old to receive recommended care.

Our results are consistent with previous reports on younger beneficiaries with respect to the proportion of those who were non-Hispanic black, who were eligible for Medicare and Medicaid [5, 33] and who self-reported to have cognitive, developmental or psychiatric disorders [6]. Younger beneficiaries demonstrated a higher prevalence of self- or proxy- reported dependencies in ADLs and IADLs in our study than previously reported [34]. The results suggest that activity limitations of younger Medicare beneficiaries have not improved over time, supporting need for interventions.

Although it has been reported that younger Medicare beneficiaries significantly underuse preventive care compared to older beneficiaries [4], our study was able to quantify the extent of such deficits. We found the most striking deficiencies across the three prevention indices, routine care for diabetes and post-discharge follow-up for CVA and TIA. Inadequate care, particularly for chronic conditions, suggests that the current service delivery model that centers on acute illness [35] does not meet current needs for prevention and chronic conditions. The reorientation of Medicare to the management of chronic illness and the amelioration of activity limitation could improve the care and reduce costs for chronically ill beneficiaries [36]. Appropriate use of preventive services, medication management and behavioral interventions have been proposed as promising strategies for reducing severity of chronic conditions and their complications [3].

Younger beneficiary status was an independent predictor of underuse in the adjusted model, possibly due to the operation of unknown factors influencing underuse in this population, such as infrequent contact with the health system, especially outpatient services. A posthoc analysis revealed that among beneficiaries with a cognitive, developmental or psychiatric disorder, the three age groups made similar numbers of outpatient visits (Median =2.2, 2.1 and 1.9 respectively); in contrast, among beneficiaries without those disorders, younger beneficiaries visited a doctor more often than the younger old and older old beneficiaries (Median $=2.1$ vs. 1.0 and 1.5). The excess office visits made by younger beneficiaries were likely due to Medicare eligible conditions other than cognitive, developmental or psychiatric disorders. These findings suggest that a greater number of office visits does not necessarily translate into adequate care for younger beneficiaries. One explanation for the paradox is that specialists may not make

Table 2 Receipt of recommended care among medicare beneficiaries (2001-2008) by age group at the indicator level

\begin{tabular}{|c|c|c|c|c|}
\hline & Overall & Age $<65$ & Age $65-74$ & Age $\geq 75$ \\
\hline Total number of opportunities for recommended care (unweighted denominator) & 89,076 & 14,015 & 32,372 & 42,689 \\
\hline Total number of instances of recommended care received (unweighted numerator) & 64,157 & 8702 & 23,582 & 31,873 \\
\hline Weighted percent of recommended care received & $72.1 \%$ & $63.9 \%$ & $72.7 \%$ & $74.8 \%$ \\
\hline
\end{tabular}


Table 3 Receipt of recommended care by indicator among medicare beneficiaries (2001-2008) by age group

\begin{tabular}{|c|c|c|c|c|c|c|}
\hline \multirow[t]{2}{*}{ Recommended care indicator } & \multicolumn{2}{|l|}{$\begin{array}{l}\text { Overall } \\
N=30,117\end{array}$} & \multirow{2}{*}{$\begin{array}{l}\text { Age }<65 \\
5201(16.3 \%) \\
\text { Weighted } \\
\text { percent }(\%)\end{array}$} & \multirow{2}{*}{$\begin{array}{l}\text { Age } 65-74 \\
11,289(47.5 \%) \\
\text { Weighted } \\
\text { percent (\%) }\end{array}$} & \multirow{2}{*}{$\begin{array}{l}\text { Age } \geq 75 \\
13,627(36.2 \%) \\
\text { Weighted } \\
\text { percent (\%) }\end{array}$} & \multirow{2}{*}{$\begin{array}{l}P \text {-value for } \\
\text { difference } \\
\text { among age } \\
\text { groups }\end{array}$} \\
\hline & $\begin{array}{l}\text { Raw numerator/ } \\
\text { denominator }\end{array}$ & $\begin{array}{l}\text { Weighted } \\
\text { percent (\%) }\end{array}$ & & & & \\
\hline \multicolumn{7}{|l|}{ Acute Myocardial Infarction (AMI) } \\
\hline $\begin{array}{l}\text { Visit within } 4 \text { weeks following } \\
\text { discharge of patients hospitalized } \\
\text { for acute myocardial infarction }\end{array}$ & $231 / 298$ & 79 & 84 & 79 & 78 & 0.748 \\
\hline $\begin{array}{l}\text { Cholesterol test every } 6 \text { months } \\
\text { for patients hospitalized for } \\
\text { myocardial infarction who have } \\
\text { hypercholesterolemia }\end{array}$ & $224 / 365$ & 64 & 71 & 69 & 58 & 0.188 \\
\hline \multicolumn{7}{|l|}{ Anemia } \\
\hline $\begin{array}{l}\text { Gastrointestinal workup for } \\
\text { patients with iron deficiency } \\
\text { anemia no later than } 3 \text { months } \\
\text { after iron deficiency }\end{array}$ & $355 / 1112$ & 33 & 34 & 37 & 30 & 0.273 \\
\hline $\begin{array}{l}\text { Hematocrit/hemoglobin between } \\
1 \text { and } 6 \text { months following initial } \\
\text { diagnosis of anemia }\end{array}$ & $1723 / 2576$ & 68 & 67 & 67 & 69 & 0.633 \\
\hline \multicolumn{7}{|l|}{ Angina } \\
\hline $\begin{array}{l}\text { Visit within } 4 \text { weeks following } \\
\text { discharge of patients hospitalized } \\
\text { for unstable angina }\end{array}$ & $193 / 234$ & 83 & 76 & 83 & 86 & 0.407 \\
\hline $\begin{array}{l}\text { Visit every } 6 \text { months for patients } \\
\text { with chronic stable angina }\end{array}$ & 1826/1940 & 94 & 92 & 93 & 96 & 0.135 \\
\hline $\begin{array}{l}\text { Follow-up visit or hospitalization } \\
\text { within } 4 \text { weeks of initial diagnosis } \\
\text { of unstable angina }\end{array}$ & $196 / 236$ & 84 & 77 & 82 & 89 & 0.150 \\
\hline $\begin{array}{l}\text { Lipid profile within } 6 \text { months after } \\
\text { initial diagnosis of angina }\end{array}$ & $59 / 767$ & 9 & $x$ & 14 & 4 & 0.0003 \\
\hline \multicolumn{7}{|l|}{ Breast Cancer } \\
\hline $\begin{array}{l}\text { Interval from biopsy and definitive } \\
\text { therapy less than } 3 \text { months for } \\
\text { patients with breast cancer and } \\
\text { eventual mastectomy }\end{array}$ & $60 / 79$ & 73 & $x$ & 70 & 81 & 0.273 \\
\hline $\begin{array}{l}\text { Mammogram within } 3 \text { months } \\
\text { preceding an initial diagnosis of } \\
\text { breast cancer }\end{array}$ & $110 / 182$ & 61 & $x$ & 60 & 63 & 0.917 \\
\hline $\begin{array}{l}\text { Chest } x \text {-ray within } 3 \text { months } \\
\text { preceding or following initial } \\
\text { diagnosis of breast cancer }\end{array}$ & $96 / 182$ & 51 & 43 & 54 & 51 & 0.631 \\
\hline $\begin{array}{l}\text { Visit within } 12 \text { months for breast } \\
\text { cancer patients who have } \\
\text { undergone mastectomy without } \\
\text { cytotoxic chemotherapy }\end{array}$ & $71 / 71$ & 100 & $x$ & 100 & 100 & $\mathrm{~N} / \mathrm{A}$ \\
\hline $\begin{array}{l}\text { Mammography every year for } \\
\text { patients with a history of breast } \\
\text { cancer }\end{array}$ & $416 / 629$ & 69 & 70 & 78 & 61 & 0.0004 \\
\hline \multicolumn{7}{|l|}{ Cerebrovascular Accident (CVA) } \\
\hline $\begin{array}{l}\text { Carotid imaging within } 2 \text { weeks of } \\
\text { initial diagnosis for patients } \\
\text { hospitalized for carotid artery } \\
\text { stroke }\end{array}$ & $235 / 312$ & 75 & 95 & 68 & 75 & $<.0001$ \\
\hline $\begin{array}{l}\text { Interval between carotid imaging } \\
\text { and carotid endarterectomy less } \\
\text { than } 2 \text { months for cerebrovascular }\end{array}$ & $112 / 134$ & 84 & $x$ & 87 & 83 & 0.501 \\
\hline
\end{tabular}


Table 3 Receipt of recommended care by indicator among medicare beneficiaries (2001-2008) by age group (Continued)

\begin{tabular}{|c|c|c|c|c|c|c|}
\hline \multicolumn{7}{|l|}{$\begin{array}{l}\text { accident patients with eventual } \\
\text { carotid endarterectomy }\end{array}$} \\
\hline $\begin{array}{l}\text { Visit within } 4 \text { weeks following } \\
\text { discharge of patients for } \\
\text { cerebrovascular accident }\end{array}$ & $379 / 571$ & 67 & 57 & 75 & 64 & 0.011 \\
\hline \multicolumn{7}{|l|}{ Transient Ischemic Attack (TIA) } \\
\hline $\begin{array}{l}\text { Electrocardiogram within } 2 \text { days of } \\
\text { initial diagnosis of transient } \\
\text { ischemic attack }\end{array}$ & $92 / 621$ & 15 & $x$ & 16 & 14 & 0.748 \\
\hline $\begin{array}{l}\text { Interval between carotid imaging } \\
\text { and carotid endarterectomy less } \\
\text { than } 2 \text { months for TIA patients } \\
\text { with eventual carotid } \\
\text { endarterectomy }\end{array}$ & $45 / 54$ & 85 & $x$ & 91 & 82 & 0.012 \\
\hline $\begin{array}{l}\text { Visit within } 4 \text { weeks following } \\
\text { discharge of patients hospitalized } \\
\text { for transient ischemic attack }\end{array}$ & $184 / 237$ & 79 & 61 & 95 & 74 & $<.0001$ \\
\hline $\begin{array}{l}\text { Visit every year for patients with } \\
\text { diagnosis of transient ischemic } \\
\text { attack }\end{array}$ & $1540 / 1596$ & 97 & 96 & 97 & 96 & 0.740 \\
\hline \multicolumn{7}{|l|}{ Cholelithiasis } \\
\hline $\begin{array}{l}\text { Cholecystectomy within } 1 \text { month } \\
\text { preceding or } 3 \text { months following } \\
\text { diagnosis of cholelithiasis and one } \\
\text { or more of the following: } \\
\text { cholecystitis, cholangitis, gallstone } \\
\text { pancreatitis }\end{array}$ & 282/699 & 41 & 43 & 48 & 34 & 0.030 \\
\hline \multicolumn{7}{|c|}{ Chronic Obstructive Pulmonary Disease (COPD) } \\
\hline $\begin{array}{l}\text { Visit every } 6 \text { months for patients } \\
\text { with chronic obstructive } \\
\text { pulmonary disease }\end{array}$ & $4732 / 5197$ & 91 & 90 & 91 & 92 & 0.236 \\
\hline \multicolumn{7}{|l|}{ Congestive Heart Failure (CHF) } \\
\hline $\begin{array}{l}\text { Chest x-ray within } 3 \text { months of } \\
\text { initial diagnosis of congestive } \\
\text { heart failure }\end{array}$ & $1097 / 1580$ & 69 & 72 & 64 & 71 & 0.067 \\
\hline $\begin{array}{l}\text { Electrocardiogram within } \\
3 \text { months of initial diagnosis of } \\
\text { congestive heart failure }\end{array}$ & $1023 / 1578$ & 66 & 67 & 66 & 66 & 0.953 \\
\hline $\begin{array}{l}\text { Visit within } 4 \text { weeks following } \\
\text { discharge of patients hospitalized } \\
\text { for congestive heart failure }\end{array}$ & $490 / 663$ & 74 & 71 & 82 & 70 & 0.032 \\
\hline $\begin{array}{l}\text { Visit every } 6 \text { months for patients } \\
\text { with congestive heart failure }\end{array}$ & $4142 / 4527$ & 92 & 91 & 93 & 91 & 0.201 \\
\hline \multicolumn{7}{|l|}{ Depression } \\
\hline $\begin{array}{l}\text { Visit within } 2 \text { weeks following } \\
\text { discharge of patients hospitalized } \\
\text { for depression }\end{array}$ & $95 / 173$ & 53 & 49 & 55 & 57 & 0.593 \\
\hline \multicolumn{7}{|l|}{ Diabetes Mellitus (DM) } \\
\hline $\begin{array}{l}\text { Glycosylated hemoglobin every } \\
6 \text { months for patients with } \\
\text { diabetes }\end{array}$ & $3499 / 6756$ & 54 & 52 & 58 & 50 & $<.0001$ \\
\hline $\begin{array}{l}\text { Eye exam every year for patients } \\
\text { with diabetes }\end{array}$ & $3160 / 6491$ & 49 & 34 & 50 & 54 & $<.0001$ \\
\hline $\begin{array}{l}\text { Visit within } 4 \text { weeks following } \\
\text { discharge of patients hospitalized }\end{array}$ & $295 / 430$ & 68 & 71 & 63 & 70 & 0.466 \\
\hline
\end{tabular}


Table 3 Receipt of recommended care by indicator among medicare beneficiaries (2001-2008) by age group (Continued)

\begin{tabular}{|c|c|c|c|c|c|c|}
\hline $\begin{array}{l}\text { Visit every } 6 \text { months for patients } \\
\text { with diabetes }\end{array}$ & $6185 / 6756$ & 92 & 89 & 92 & 92 & 0.036 \\
\hline \multicolumn{7}{|l|}{ Gastrointestinal Bleeding } \\
\hline $\begin{array}{l}\text { Visit within } 4 \text { weeks following } \\
\text { discharge of patients hospitalized } \\
\text { for gastrointestinal bleeding }\end{array}$ & $273 / 373$ & 73 & 51 & 74 & 78 & 0.001 \\
\hline $\begin{array}{l}\text { Hematocrit within } 4 \text { weeks } \\
\text { following discharge of patients } \\
\text { hospitalized for gastrointestinal } \\
\text { bleeding }\end{array}$ & $201 / 373$ & 54 & 36 & 57 & 58 & 0.025 \\
\hline $\begin{array}{l}\text { Follow-up visit within } 4 \text { weeks of } \\
\text { initial diagnosis of gastrointestinal } \\
\text { bleeding }\end{array}$ & $491 / 676$ & 74 & 74 & 77 & 69 & 0.195 \\
\hline \multicolumn{7}{|l|}{ Hypertension } \\
\hline $\begin{array}{l}\text { Visit within } 4 \text { weeks following } \\
\text { discharge of patients hospitalized } \\
\text { with malignant or otherwise } \\
\text { severe hypertension }\end{array}$ & $49 / 74$ & 63 & $x$ & 62 & 76 & 0.0002 \\
\hline \multicolumn{7}{|l|}{ Preventive Care } \\
\hline Visit every year & $17,905 / 19,535$ & 92 & 87 & 91 & 94 & $<.0001$ \\
\hline $\begin{array}{l}\text { Assessment of visual impairment } \\
\text { every } 2 \text { years }\end{array}$ & $9363 / 16,759$ & 56 & 34 & 57 & 64 & $<.0001$ \\
\hline $\begin{array}{l}\text { Mammography every } 2 \text { years for } \\
\text { females aged between } 45 \text { and } 75 \\
\text { (inclusive) years }\end{array}$ & $2728 / 4240$ & 65 & 58 & 67 & 61 & $<.0001$ \\
\hline
\end{tabular}

Note. According to the Centers for Medicare and Medicaid Services, cell size below 11, marked with an X, is not permitted for publication

recommendations for preventive care outside their area of specialty. We speculate that improved care coordination among mental health, primary care and specialty care providers may contribute to a better understanding of patients' comprehensive care needs and making critical recommendations.

In contrast, older old beneficiaries had a slightly better chance to get recommended care than the younger old, all else equal. This is consistent with our post-hoc finding that on average older old beneficiaries visited their doctors more often than the younger old. We found greater comorbidity associated with greater likelihood of receiving appropriate care, similar to published reports [26, 37]. Increased use of recommended care for both groups is likely due to their frequent office visits leading to a greater chance to fulfill care requirements.

As expected, non-Hispanic black race, less than high-school education, non-Metropolitan residence and

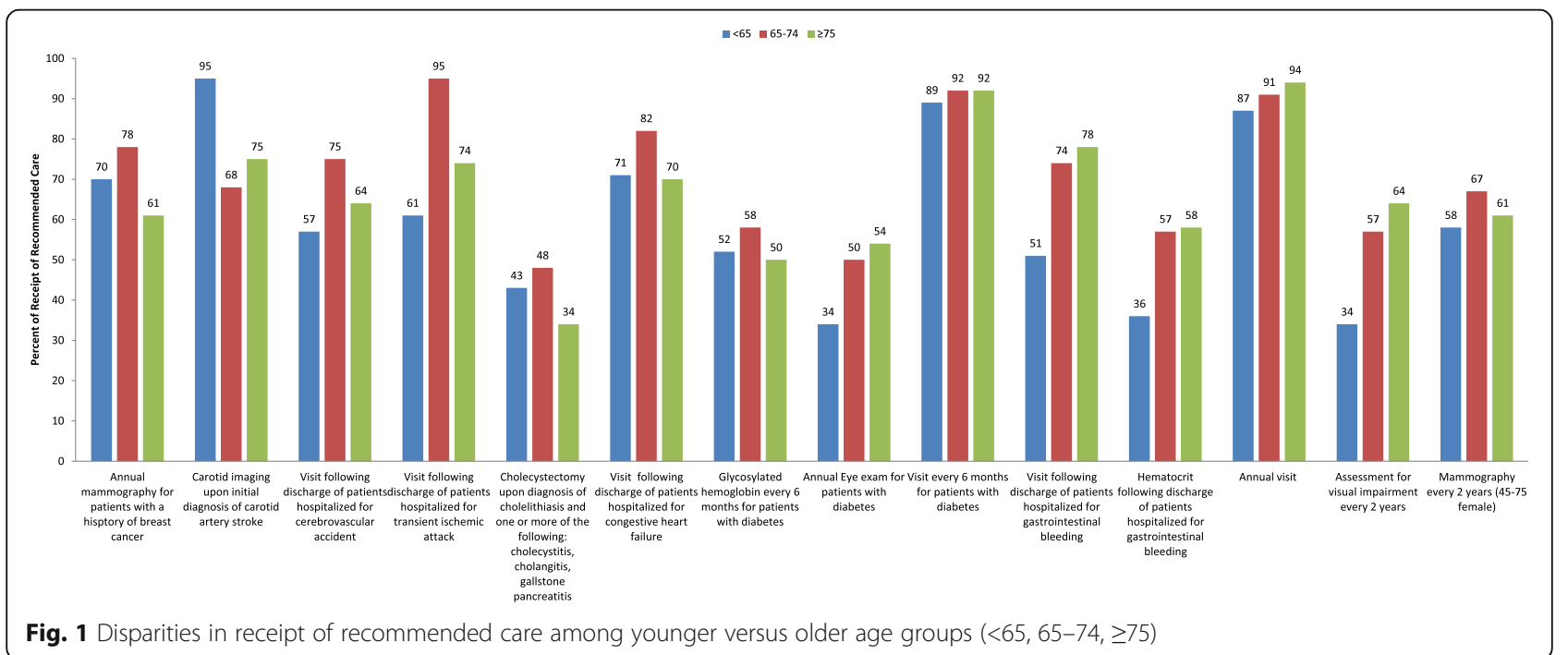


Table 4 Logistic Regression Models Predicting Receipt of Recommended Care among Medicare Beneficiaries (2001-2008)

\begin{tabular}{|c|c|c|c|c|c|c|}
\hline \multirow[t]{2}{*}{ Variables } & \multicolumn{2}{|l|}{ Model 1} & \multicolumn{2}{|c|}{ Model 2 with ADL stages } & \multicolumn{2}{|c|}{ Model 2 with IADL stages } \\
\hline & $\mathrm{OR}(95 \% \mathrm{Cl})$ & $p$-value & $\mathrm{OR}(95 \% \mathrm{Cl})$ & $p$-value & $\mathrm{OR}(95 \% \mathrm{Cl})$ & $p$-value \\
\hline Age (ref: 65-74) & & $<.0001$ & & $<.0001$ & & $<.0001$ \\
\hline$<65$ & $0.66(0.62-0.71)$ & $<.0001$ & $0.75(0.70-0.80)$ & $<.0001$ & $0.75(0.69-0.80)$ & $<.0001$ \\
\hline$\geq 75$ & $1.11(1.07-1.16)$ & $<.0001$ & $1.15(1.10-1.20)$ & $<.0001$ & $1.15(1.10-1.20)$ & $<.0001$ \\
\hline \multicolumn{7}{|l|}{ Gender (ref: female) } \\
\hline Male & & & $0.86(0.82-0.90)$ & $<.0001$ & $0.86(0.82-0.90)$ & $<.0001$ \\
\hline Race/Ethnicity (ref: Non-Hispanic White) & & & & 0.005 & & 0.005 \\
\hline Hispanic & & & $0.95(0.87-1.05)$ & 0.337 & $0.95(0.86-1.04)$ & 0.277 \\
\hline Non-Hispanic Black & & & $0.88(0.82-0.95)$ & 0.0004 & $0.88(0.82-0.95)$ & 0.0005 \\
\hline Other & & & $0.96(0.86-1.08)$ & 0.527 & $0.96(0.85-1.08)$ & 0.464 \\
\hline \multicolumn{7}{|l|}{ Education (ref: high school diploma) } \\
\hline No high school diploma & & & $0.85(0.81-0.89)$ & $<.0001$ & $0.85(0.81-0.89)$ & $<.0001$ \\
\hline Living Arrangement (ref: live with spouse) & & & & $<.0001$ & & $<.0001$ \\
\hline Alone & & & $0.88(0.83-0.92)$ & $<.0001$ & $0.87(0.83-0.92)$ & $<.0001$ \\
\hline Retirement community & & & $0.95(0.87-1.03)$ & 0.199 & $0.95(0.87-1.03)$ & 0.188 \\
\hline With children & & & $0.77(0.72-0.83)$ & $<.0001$ & $0.77(0.72-0.83)$ & $<.0001$ \\
\hline With others & & & $0.82(0.75-0.89)$ & $<.0001$ & $0.83(0.76-0.90)$ & $<.0001$ \\
\hline \multicolumn{7}{|l|}{ Residential Location (ref: Non-Metropolitan location) } \\
\hline Metropolitan location & & & $1.14(1.09-1.18)$ & $<.0001$ & $1.13(1.08-1.18)$ & $<.0001$ \\
\hline \multicolumn{7}{|c|}{ Dual Enrollment in Medicare and Medicaid (ref: Medicare only) } \\
\hline Dual enrollment & & & $1.06(1.00-1.13)$ & 0.056 & $1.06(1.00-1.13)$ & 0.072 \\
\hline \multicolumn{7}{|l|}{ Proxy Response (ref: no) } \\
\hline Proxy & & & $0.87(0.81-0.93)$ & $<.0001$ & $0.90(0.84-0.96)$ & 0.003 \\
\hline \multicolumn{7}{|l|}{ Conditions (ref: no) } \\
\hline Vision impairment & & & $1.01(0.94-1.09)$ & 0.731 & $1.02(0.94-1.10)$ & 0.694 \\
\hline Hearing impairment & & & $0.95(0.88-1.02)$ & 0.162 & $0.96(0.89-1.03)$ & 0.242 \\
\hline Cognitive, developmental, and psychiatric disorders* & & & $0.89(0.83-0.94)$ & $<.0001$ & $0.90(0.84-0.96)$ & $<.0001$ \\
\hline Sum of comorbidities** & & & $1.12(1.11-1.14)$ & $<.0001$ & $1.12(1.10-1.13)$ & 0.001 \\
\hline Stage (ref: Stage 0) & & & & $<.0001$ & & $<.0001$ \\
\hline Stage I & & & $0.92(0.88-0.97)$ & 0.003 & $0.99(0.94-1.05)$ & 0.763 \\
\hline Stage ॥ & & & $0.87(0.81-0.93)$ & $<.0001$ & $0.89(0.84-0.96)$ & 0.001 \\
\hline Stage III & & & $0.80(0.74-0.87)$ & $<.0001$ & $0.87(0.81-0.93)$ & $<.0001$ \\
\hline Stage IV & & & $0.64(0.54-0.76)$ & $<.0001$ & $0.69(0.61-0.78)$ & $<.0001$ \\
\hline
\end{tabular}

Note: Ref=reference category. For a variable that has more than two categories, a total $p$ value of the variable is reported

Model 1 is adjusted only for age group; model 2's are further adjusted for sociodemographics, health and clinical characteristics and ADL stages and IADL stages separately

* Cognitive, developmental, and psychiatric disorders include: mental retardation, Alzheimer's/dementia, and mental/psychiatric disorder

* Sum of comorbidities include: hypertension, myocardial infarction, angina/chronic heart disease, other heart disease, stroke, diabetes mellitus, Parkinson's disease, emphysema/asthma/chronic obstructive pulmonary disease, rheumatoid arthritis, non-rheumatoid arthritis, osteoporosis/soft bones, and other (non-skin) cancer

disability independently predicted underuse of care. Although reversed racial disparity has been reported [27], likely due to selection bias of the samples [38], different sets of quality of care indicators studied, and use of claims versus self-reported data, underuse of medical care among racial minorities is more accentuated in literature [21, 39]. Improving surveillance data systems, creating a culturally- competent medical workforce and recruiting minority health professionals have emerged as strategies to address racial/ethnic differences in health and health care $[40,41]$. Lower socioeconomic position [42] and rural settings $[43,44]$ diminish the chance to obtaining cancer prevention services. Removal of access barriers to care, especially financial barriers, was endorsed as central to create equity 
in health outcomes across different socioeconomic groups [45]. Availability of services, knowledge or physician recommendations of needed care and transportation are often reported factors underlying the geographic disparities in care and are points to address in interventions $[43,44]$ Greater use of home care in rural areas was also reported [46]. Future research may investigate populationlevel utilization of a wide range of health services. Disability is a known risk factor for underuse of certain care among Medicare beneficiaries excluding younger beneficiaries $[24,25]$. This is also reflected in our study, which found a monotonic increase in care disparities with higher activity limitation stages (greater severity). Physical barriers, lack of professional assistance and social support, as well as experiences of distress likely influence service underuse $[47,48]$. Resource reallocation targeting disabled individuals may aid their access to care and increase use of recommended care. Furthermore, since functional decline after hospitalization is fairly common [49], establishing care continuity in communities after hospital discharge can be critical for disabled persons.

We studied three Medicare age groups who likely occupy different positions in a social hierarchy and differ in their health status and utilization of health services. Such comparison is useful in identifying a disadvantaged population and its care needs, which subsequently informs resource reallocation to achieve greater equity. The study has several limitations. This study does not answer the question why younger beneficiaries underuse recommended care. The mechanism can be explained by access barriers to care, care not recommended by providers, or care recommended by providers but was not sought by the patient. For instance, some beneficiaries did not seek or comply with recommended care because of their limited health literacy or knowledge about their care plans $[50,51]$. It has also been reported that providers tend to downplay the importance of healthy behaviors and disease prevention in the lives of their disabled patients [47]. Due to data limitation, we were not able to incorporate these potential causes for failure of care compliance in our analysis. We recommend in-depth observational studies that explore patient-doctor encounters to determine the causes of underuse and what types of appropriate preventions should be in place. Asch's indicator system reflects care needs of highly prevalent conditions among the elderly population. These indicators may not reflect all care needs of younger beneficiaries, especially those experiencing cognitive, developmental or psychiatric disorders. Indicators that address the care for prevalent diseases in younger beneficiaries are highly desirable. Stratified analysis of receipt of recommended care among beneficiaries with versus without psychiatric disorders may also be considered, since persons who have been admitted for mental disorders tend to have poorer quality of care and higher mortality in somatic diseases, compared to persons who only have somatic diseases [52]. We acknowledge the likelihood of residual confounding in socioeconomic, comorbidity and to a lesser extent disability, measures. It is possible that even after controlling for all these variables, the reason of underuse among younger beneficiaries is that they are still sicker and more disadvantaged, rather than an independent effect of younger beneficiary status. Although there may be geographic variations in receipt of recommended care, MCBS is not powered to investigate state-level estimates. MCBS claims data (2002-2010) used in this study are not the most recent; however, the structure of the Medicare program eligibility for those under 65 has not changed, and the historical data matches the period when Asch's indicators were developed. Due to incomplete claims data from beneficiaries enrolled in a managed care program, our results only apply to the feefor-service Medicare population. Even though we combined eight beneficiary cohorts to compensate for small sample sizes associated with certain indicators, some indicators could not be addressed in the younger beneficiaries since cell sizes were still too small to report.

\section{Conclusions}

Our study has identified social and medical vulnerabilities of younger Medicare beneficiaries, and their lack of overall and specific type of care. Our results based on improved indicator metrics corroborated previous findings of potential influences on health service underutilization. CMS (Quality Strategy 2016) envisions care as valued-based: person-centered, cost-efficient and health-promoting [53]. It sets effective communication and coordination of care, prevention and treatment of chronic diseases, and partnership with communities to promote healthy living as among its goals, and eliminating racial and ethnic disparities and strengthening infrastructure and data systems as part of its foundational principles. Our findings provide evidence for the need of interventions that may bridge the health equity gap in the Medicare population.

\section{Acknowledgments \\ The authors thank Margaret G. Stineman, MD, for conceptualizing the study, obtaining funding and providing input in the manuscript. \\ Funding \\ The research for this manuscript was supported by grants from the National Institutes of Health (R01AG040105). \\ Availability of data and materials \\ The data that support the findings of this study are available from Centers for Medicare and Medicaid Services (CMS)'s Medicare Current Beneficiary Survey. CMS has granted our research team access to the survey data. However, restrictions apply to the availability of the full data, which were used under license for the NIH-grant funded project, and so are not publicly available.}

\section{Authors' contributions}

LN contributed to the conceptualization and design of the study, data analysis and interpretation, and writing of the manuscript; JS, LP, JK, DX, HB contributed to the conceptualization and design of the study, data interpretation and 
critical review of the manuscript; FK contributed to conceptualization and design of the study, data analysis and interpretation and review of the manuscript; SA critically reviewed the manuscript; SH contributed to the conceptualization and design of the study, data interpretation, critical review and revision of the manuscript. All authors read and approved the final manuscript.

\section{Competing interests}

The authors declare that they have no competing interests.

\section{Consent for publication}

Not applicable.

\section{Ethics approval and consent to participate}

The study was approved by the University of Pennsylvania Institutional Review Board, with approval number 817595. Consent to participate in this study was not applicable.

\section{Disclosures}

The research for this manuscript was supported by grants from the National Institutes of Health (R01HD074756). There are no personal conflicts of interest of any of the authors in the past 3 years, and no authors reported disclosures beyond the funding source. The opinions and conclusions of the authors are not necessarily those of the sponsoring agency. We certify that no party having a direct interest in the results of the research supporting this article has or will confer a benefit on us or on any organization with which we are associated. This material has not been previously presented at a meeting.

\section{Publisher's Note}

Springer Nature remains neutral with regard to jurisdictional claims in published maps and institutional affiliations.

\section{Author details}

${ }^{1}$ Center for Clinical Epidemiology and Biostatistics, Perelman School of Medicine, University of Pennsylvania, Philadelphia, PA, USA. ${ }^{2}$ Geriatric Psychiatry Section of the Department of Psychiatry, Perelman School of Medicine, University of Pennsylvania, Philadelphia, PA, USA. ${ }^{3}$ Center for Patient Care and Outcomes Research (PCOR), Medical College of Wisconsin, Milwaukee, WI, USA. ${ }^{4}$ Department of Medicine, Medical College of Wisconsin, Milwaukee, WI, USA. ${ }^{5}$ Division of General Medical Disciplines, Stanford University School of Medicine, Menlo Park, CA, USA. ${ }^{6}$ Center for Pharmacoepidemiology Research and Training, University of Pennsylvania, Philadelphia, PA, USA.

Received: 17 August 2016 Accepted: 16 March 2017 Published online: 29 March 2017

\section{References}

1. HealthyPeople.gov 2020. Disparities. 2015. http://www.healthypeople.gov/ 2020/about/foundation-health-measures/Disparities. Accessed 29 Dec 2015.

2. Social Security Administration. Social Security: Medicare. https://www.ssa. gov/pubs/EN-05-10043.pdf. Accessed 8 Dec 2015.

3. Kennedy J, Tuleu IB. Working age medicare beneficiaries with disabilities: population characteristics and policy considerations. J Health Hum Serv Adm. 2007;30(3):268-91.

4. Cubanski J, Neuman P. Medicare doesn't work as well for younger, disabled beneficiaries as it does for older enrollees. Health Aff. 2010;29(9):1725-33.

5. lezzoni LI. Quality of care for medicare beneficiaries with disabilities under the age of 65 years. Expert Rev Pharmacoecon Outcomes Res. 2006;6(3):261-73.

6. Foote SM, Hogan C. Disability profile and health care costs of medicare beneficiaries under age sixty-five. Health Aff (Millwood). 2001;20(6):242-53.

7. Centers for Medicare and Medicaid Services. Medicare and Medicaid Statistical Supplement. https://www.cms.gov/Research-Statistics-Data-andSystems/Statistics-Trends-and-Reports/MedicareMedicaidStatSupp. Accessed 30 Nov 2015

8. Braveman P. Health disparities and health equity: concepts and measurement. Annu Rev Public Health. 2006;27:167-94.

9. Donabedian A. Explorations in quality assessment and monitoring, The definition of quality and approaches to its assessment, vol. 1. Ann Arbor: Health Administration Press; 1980.
10. Campbell SM, Roland MO, Buetow SA. Defining quality of care. Soc Sci Med. 2000:51(11):1611-25.

11. Braveman P, Gruskin S. Defining equity in health. J Epidemiol Community Health. 2003:57(4):254-8.

12. Peek ME, Cargill A, Huang ES. Diabetes health disparities: a systematic review of health care interventions. Med Care Res Rev. 2007;64(5 Suppl):101S-56S.

13. Centers for Disease Control and Prevention. The CDC Health Disparities \& Inequalities Report - United States. 2013. http://www.cdc.gov/ DisparitiesAnalytics/topic_table.html. Accessed 5 Dec 2015.

14. Adler NE, Stewart J. Health disparities across the lifespan: meaning, methods, and mechanisms. Ann N Y Acad Sci. 2010;1186:5-23.

15. Hennessy S, Kurichi JE, Pan Q, Streim JE, Bogner HR, Xie D, Stineman MG. Disability stage is an independent risk factor for mortality in medicare beneficiaries aged 65 years and older. PM R. 2015;7(12):1215-25.

16. Stineman MG, Xie D, Pan Q, Kurichi JE, Zhang Z, Saliba D, Henry-Sanchez JT, Streim J. All-cause 1-, 5-, and 10-year mortality in elderly people according to activities of daily living stage. J Am Geriatr Soc. 2012;60(3):485-92.

17. HealthyPeople.gov 2020. Topics and Objectives: Disability and Health. http://www.healthypeople.gov/2020/topics-objectives/topic/disability-andhealth\#two. Accessed 15 Dec 2015.

18. Roos LL, Walld R, Uhanova J, Bond R. Physician visits, hospitalizations, and socioeconomic status: ambulatory care sensitive conditions in a Canadian setting. Health Serv Res. 2005;40(4):1167-85.

19. Laditka JN. Hazards of hospitalization for ambulatory care sensitive conditions among older women: evidence of greater risks for African Americans and Hispanics. Med Care Res Rev. 2003;60(4):468-95. discussion 496-508.

20. Laditka JN, Laditka SB, Probst JC. Health care access in rural areas: evidence that hospitalization for ambulatory care-sensitive conditions in the United States may increase with the level of rurality. Health Place. 2009;15(3):731-40.

21. Asch SM, Sloss EM, Hogan C, Brook RH, Kravitz RL. Measuring underuse of necessary care among elderly medicare beneficiaries using inpatient and outpatient claims. JAMA. 2000;284(18):2325-33.

22. Laditka JN, Laditka SB, Probst JC. More may be better: evidence of a negative relationship between physician supply and hospitalization for ambulatory care sensitive conditions. Health Serv Res. 2005;40(4):1148-66.

23. Fiscella K, Franks P, Gold MR, Clancy CM. Inequality in quality: addressing socioeconomic, racial, and ethnic disparities in health care. JAMA. 2000;283(19):2579-84.

24. Chan L, Ciol MA, Shumway-Cook A, Yorkston KM, Dudgeon BJ, Asch SM, Hoffman JM. A longitudinal evaluation of persons with disabilities: does a longitudinal definition help define who receives necessary care? Arch Phys Med Rehabil. 2008;89(6):1023-30.

25. Chan L, Doctor JN, MacLehose RF, Lawson H, Rosenblatt RA, Baldwin LM, Jha A. Do medicare patients with disabilities receive preventive services? a population-based study. Arch Phys Med Rehabil. 1999;80(6):642-6.

26. Higashi T, Wenger NS, Adams JL, Fung C, Roland M, McGlynn EA, Reeves D, Asch SM, Kerr EA, Shekelle PG. Relationship between number of medical conditions and quality of care. N Engl J Med. 2007;356(24): 2496-504.

27. Asch SM, Kerr EA, Keesey J, Adams JL, Setodji CM, Malik S, McGlynn EA. Who is at greatest risk for receiving poor-quality health care? N Engl J Med. 2006:354(11):1147-56.

28. Centers for Medicare and Medicaid Services. Medicare Current Beneficiary Survey (MCBS). http://www.cms.gov/Research-Statistics-Data-and-Systems/ Research/MCBS/index.html?redirect=/MCBS. Accessed 10 Oct 2015.

29. Kautter J, Khatutsky G, Pope GC, Chromy JR, Adler GS. Impact of nonresponse on medicare current beneficiary survey estimates. Health Care Financ Rev. 2006;27(4):71-93.

30. World Health Organization. International Classification of Functioning, Disability and Health: ICF. Geneva: World Health Organization; 2001.

31. Stineman MG, Streim JE, Pan Q, Kurichi JE, Schussler-Fiorenza Rose SM, Xie D. Activity limitation stages empirically derived for Activities of Daily Living $(A D L)$ and instrumental $A D L$ in the U.S. adult community-dwelling medicare population. PM R. 2014;6(11):976-87.

32. Kurichi JE, Streim JE, Bogner HR, Xie D, Kwong PL, Hennessy S. Comparison of predictive value of activity limitation staging systems based on dichotomous versus trichotomous responses in the medicare current beneficiary survey. Disabil Health J. 2016;9(1):64-73.

33. Davis $\mathrm{MH}, \mathrm{O}^{\prime}$ Brien E. Profile of persons with disabilities in medicare and medicaid. Health Care Financ Rev. 1996;17(4):179-211. 
34. Cubanski J, Huang J, Damico A, Jacobson G, Neuman T, Kaiser Foundation. Medicare Chartbook. Kaiser Family Foundation; 2010. https:/kaiserfamilyfoundation files.wordpress.com/2013/01/8103.pdf. Accessed 29 Dec 2015.

35. Kizer KW. The emerging imperative for health care quality improvement. Acad Emerg Med. 2002;9(11):1078-84.

36. Daaleman TP. Reorganizing medicare for older adults with chronic illness. J Am Board Fam Med. 2006;19(3):303-9.

37. Min LC, Elliott MN, Wenger NS, Saliba D. Higher vulnerable elders survey scores predict death and functional decline in vulnerable older people. J Am Geriatr Soc. 2006;54(3):507-11.

38. Geiger HJ, Betancourt JR, Williams DR. Who is at greatest risk for receiving poor-quality health care? N Engl J Med. 2006;354(24):2617-9.

39. McBean AM, Gornick M. Differences by race in the rates of procedures performed in hospitals for medicare beneficiaries. Health Care Financ Rev. 1994:15(4):77-90.

40. Williams DR, Rucker TD. Understanding and addressing racial disparities in health care. Health Care Financ Rev. 2000;21(4):75-90.

41. Betancourt JR, Green AR, Carrillo JE, Ananeh-Firempong 2nd O. Defining cultural competence: a practical framework for addressing racial/ethnic disparities in health and health care. Public Health Rep. 2003;118(4):293-302.

42. Hahn RA, Teutsch SM, Franks AL, Chang MH, Lloyd EE. The prevalence of risk factors among women in the United States by race and age, 1992-1994: opportunities for primary and secondary prevention. J Am Med Womens Assoc. 1998;53(2):96-104. 107.

43. Stearns SC, Slifkin RT, Edin HM. Access to care for rural medicare beneficiaries. J Rural Health. 2000;16(1):31-42.

44. Casey MM, Thiede Call K, Klingner JM. Are rural residents less likely to obtain recommended preventive healthcare services? Am J Prev Med. 2001;21(3):182-8

45. Andrulis DP. Access to care is the centerpiece in the elimination of socioeconomic disparities in health. Ann Intern Med. 1998;129(5):412-6.

46. Dansky KH, Brannon D, Shea DG, Vasey J, Dirani R. Profiles of hospital, physician, and home health service use by older persons in rural areas. Gerontologist. 1998;38(3):320-30.

47. lezzoni LI. Eliminating health and health care disparities among the growing population of people with disabilities. Health Aff. 2011;30(10):1947-54.

48. Centers for Disease Control and Prevention. Environmental barriers to health care among persons with disabilities-Los Angeles County, California, 2002-2003. MMWR Morb Mortal Wkly Rep. 2006;55(48):1300-3.

49. Gill TM, Allore HG, Gahbauer EA, Murphy TE. Change in disability after hospitalization or restricted activity in older persons. JAMA. 2010;304(17):1919-28.

50. Sudore RL, Mehta KM, Simonsick EM, Harris TB, Newman AB, Satterfield S, Rosano C, Rooks RN, Rubin SM, Ayonayon HN, Yaffe K. Limited literacy in older people and disparities in health and healthcare access. J Am Geriatr Soc. 2006;54(5):770-6.

51. Morgan RO, Teal CR, Hasche JC, Petersen LA, Byrne MM, Paterniti DA, Virnig BA. Does poorer familiarity with Medicare translate into worse access to health care? J Am Geriatr Soc. 2008:56(11):2053-60.

52. Bjorkenstam E, Ljung R, Burstrom B, Mittendorfer-Rutz E, Hallqvist J, Weitoft GR. Quality of medical care and excess mortality in psychiatric patients-a nationwide register-based study in Sweden. BMJ Open. 2012;2:e000778.

53. Centers for Medicare and Medicaid Services. CMS quality strategy. 2016 https://www.cms.gov/medicare/quality-initiatives-patient-assessmentinstruments/qualityinitiativesgeninfo/downloads/cms-quality-strategy.pdf. Accessed 22 Mar 2016

\section{Submit your next manuscript to BioMed Central and we will help you at every step:}

- We accept pre-submission inquiries

- Our selector tool helps you to find the most relevant journal

- We provide round the clock customer support

- Convenient online submission

- Thorough peer review

- Inclusion in PubMed and all major indexing services

- Maximum visibility for your research

Submit your manuscript at www.biomedcentral.com/submit
Biomed Central 